\title{
Review of disability weight studies: comparison of methodological choices and values
}

\author{
Juanita A Haagsma ${ }^{1 *}$, Suzanne Polinder ${ }^{1}$, Alessandro Cassini ${ }^{2}$, Edoardo Colzani ${ }^{2}$ and Arie H Havelaar ${ }^{3,4}$
}

\begin{abstract}
Introduction: The disability-adjusted life year (DALY) is widely used to assess the burden of different health problems and risk factors. The disability weight, a value anchored between 0 (perfect health) and 1 (equivalent to death), is necessary to estimate the disability component (years lived with disability, YLDs) of the DALY. After publication of the ground-breaking Global Burden of Disease (GBD) 1996, alternative sets of disability weights have been developed over the past 16 years, each using different approaches with regards to the panel, health state description, and valuation methods. The objective of this study was to review all studies that developed disability weights and to critically assess the methodological design choices (health state and time description, panel composition, and valuation method). Furthermore, disability weights of eight specific conditions were compared.
\end{abstract}

Methods: Disability weights studies (1990-2012) in international peer-reviewed journals and grey literature were identified with main inclusion criteria being that the study assessed DALY disability weights for several conditions or a specific group of illnesses. Studies were collated by design and methods and evaluation of results.

Results: Twenty-two studies met the inclusion criteria of our review. There is considerable variation in methods used to derive disability weights, although most studies used a disease-specific description of the health state, a panel that consisted of medical experts, and nonpreference-based valuation method to assess the values for the majority of the disability weights. Comparisons of disability weights across 15 specific disease and injury groups showed that the subdivision of a disease into separate health states (stages) differed markedly across studies. Additionally, weights for similar health states differed, particularly in the case of mild diseases, for which the disability weight differed by a factor of two or more.

Conclusions: In terms of comparability of the resulting YLDs, the global use of the same set of disability weights has advantages, though practical constraints and intercultural differences should be taken into account into such a set.

Keywords: Value of life, Disease burden, Disability adjusted life years, Summary measure of population health, Prioritisation

\section{Introduction}

Human health is threatened by an array of diseases and injuries. Limited resources compel policymakers to focus on threats that are most relevant in terms of public health. An objective tool that aids policymakers in setting priorities in resource allocation is the disability-adjusted life year (DALY). The DALY measures the burden of disease, i.e., it aggregates the total health loss at population level into a single index by summarizing a) years of life lost due to premature death (YLLs) and b) years lived with

\footnotetext{
* Correspondence: j.haagsma@erasmusmc.nl

${ }^{1}$ Department of Public Health, Erasmus Medical Center, PO Box 2040, 3000

CA Rotterdam, The Netherlands

Full list of author information is available at the end of the article
}

disability (YLDs) [1]. In this way the DALY estimations allow comparability between the impact of diseases and provide knowledge on the size of health problems and the potential benefit of proposed measures set against similar and comparable data of other health problems $[2,3]$.

An essential factor for establishing YLDs is the disability weight, a value assigned to living with disability. This value, anchored between 0 (perfect health) and 1 (equivalent to death), reflects the impact of a specific health condition. The values of the disability weights are commonly based on preferences obtained from a panel of judges [4]. Preferences are defined as quantitative expressions or valuations for certain health states, which reflect the relative 
desirability of a health state [5,6]. Empirical research has shown that preferences are dependent on the composition of the panel, with patients valuing their disease as less unfavorable compared to the general public [7-9], though these findings have been disputed $[10,11]$. Other methodological aspects that may influence preferences for a certain health state are the way the health state and duration of the health state are described and the valuation method that is used. Each of these aspects affect the preferences that are measured, which in turn affect the values of the disability weights [12].

For the ground-breaking Global Burden of Disease (GBD) 1996 study that estimated the total burden of disease worldwide a large set of global disability weights was derived $[1,13]$. However, because of a need to validate and improve the novel valuation procedure, a need for disability weights that reflected preferences of the national population and/or because of practical limitations of the GBD 1996 disability weight (i.e., lack of disability weights for certain diseases or lack of differentiation between different health states within one disease or disease group), alternative sets of disability weights have been developed over the past 16 years, each using different approaches with regards to the panel, health state description, and valuation methods.

This review aims to provide an overview of all studies that developed disability weights and to compare the methodological design choices. Four key choices were addressed: (1) the health state description, (2) time presentation, (3) panel composition, and (4) the valuation method. Furthermore, disability weights for 15 specific disease and injury groups resulting from the disability weight studies were compared with the aim to assess the influence of the description of the health condition and other design choices on difference in the disability weights.

\section{Review}

Disability weights - design choices

Figure 1 shows a conceptual model of assessing disability weights and its four main design choices. The first choice is the health state description. The choices here are to describe the disease in generic terms or in disease-specific terms. A disease-specific description depicts the disease label and/or clinical description; it indicates the cause and/or the specific health effects of the condition. A generic health state description depicts the functional health independent of the actual underlying condition. For this purpose a multi-attribute utility instrument (MAUI) is used [14]. With MAUI, generic attributes are used to classify health states $[7,15,16]$. Firstly, patients describe their health state by choosing a functional level for each attribute. Using weights for the separate attributes, the reported functional level on the attributes is then converted into a summary score which fits within the $0-1$ range, where 1 is perfect health (the reverse direction compared to DALY weights). The weights that are used to convert the health states into a disability weight are derived at an earlier stage and are based on preference data of the general population for health states described with the generic attributes. This approach is similar to the approach that is used to derive quality-adjusted life year (QALY) weights, except that one extra step is taken to transform QALY weights into disability weights. Widely used MAUIs include the EQ-5D health questionnaire and Health Utilities Index (HUI) $[17,18]$. For the EQ-5D several tariffs exist for calculating EQ-5D summary scores. Two other ways to derive health state valuations using the EQ-5D are 1) to use the visual analog scale (VAS) that accompanies the EQ-5D and 2) to use the health description system of the EQ-5D to describe a health state, either with our without additional disease information, which is then submitted to a panel of experts or lay people to derive disability weights $[19,20]$.

The second design choice concerns the time presentation. The time presentation of the health state can be distinguished into period profiles and annual health profiles. With period profiles, the underlying assumption is that that the value of the health state is not affected by the duration of the health state [21,22]. With the annual profile approach, the course of the health state - the disability profile - is described over a period of one year $[4,23]$. This allows valuation of conditions with an acute onset, conditions with a short duration, episodic diseases such as epilepsy, and conditions that are characterized by complex and heterogeneous recovery patterns. An example of an annual profile health state description is a person who has gastroenteritis for a period of seven days but for the remainder of the year the person is healthy.

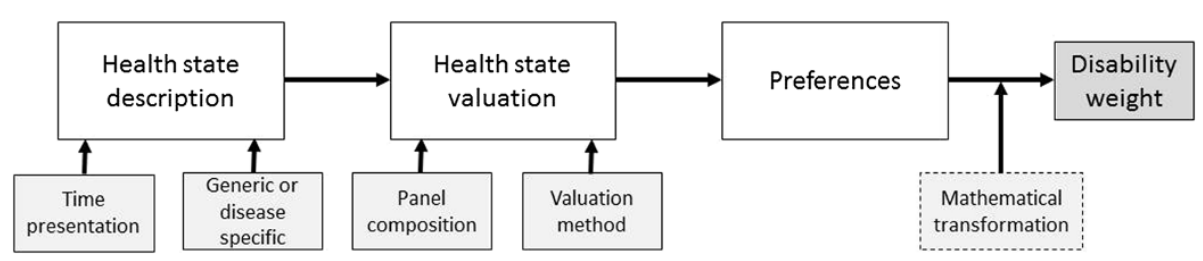

Figure 1 Conceptual model of assessing disability weights and its design choices. 
The third choice is the panel composition. The panel providing the preferences may consist of patients or valid proxies, medical experts, or members of the general public.

The fourth main design choice concerns the valuation method. To measure individual preferences, several valuation methods exist. These valuation methods include pairwise comparison, the VAS, time trade-off (TTO), person trade-off (PTO), and standard gamble (SG). Each of these valuation methods has different properties that affect the preferences that are measured. The TTO, PTO, and SG are choice-based valuation methods; asking to make trade-offs in time (TTO), person-years (PTO), or risk of death against improvement in health. For a detailed overview of these valuation methods see [24].

\section{Literature review - selection criteria and definitions}

This review is restricted to studies that assessed disability weights for burden of disease measurements, expressed in DALY estimates. Empirical studies in the international peer-reviewed journals and grey literature published in English in the period 1990 to 2012 were included. Studies in established market economies and low- and middleincome countries were all included. This review included studies that derived disability weights for several groups of health outcomes or a specific group of illnesses (for instance: periodontal disease or cancer). We excluded studies that derived a disability weight for one single health state (because these studies do not give information about the relative desirability of a health state compared to other health states), studies that derived disability weights for risk factors (such as environmental factors, e.g., noise), and studies that derived severity weights for QALYs.

\section{Literature review - data sources and search strategy} Searches of eligible studies were conducted in Medline (PubMed) and EMBASE. All international peer reviewed articles published in the period between January 1, 1990 and December 31, 2012 were included in the searches. Searches for eligible grey literature were conducted in Google Scholar. Search terms used for general burden of disease studies were: "disability weight", "severity weight", "burden of disease", "disability adjusted life year", "disability-adjusted life year", "DALY". Keywords were matched to database-specific indexing terms. In addition to database searches, reference lists of review studies and articles included in the review were screened for titles that included key terms.

\section{Literature review - data extraction}

Relevant papers were selected by screening the titles (first step), abstracts (second step), and entire articles (third step) retrieved through the database searches. During each step, respectively, the title, abstract, or entire article was screened to ensure that it met the selection criteria listed above. This screening was conducted independently by two researchers (JH and SP). Disagreement about eligibility between the reviewers was resolved through discussion.

Selected full articles were critically appraised by two reviewers ( $\mathrm{JH}$ and $\mathrm{SP}$ ), using data extraction forms, which included information on the study population, details regarding the methods used to calculate YLL and YLD, main conclusions, etc. Their reports were compared and disagreements were resolved by discussion.

\section{Comparison of disability weights}

Disability weights of 15 specific diseases/injuries were compared. We selected 15 diseases/injuries that represent the complete spectrum of severity (from mild conditions through very severe conditions) that were included in more than one disability weight study. Eleven of these health states were selected from the 22 indicator conditions of the GBD 1996 study. The four other conditions were selected because one or more of the disability weights studies focused on this single cause of disease (e.g., periodontal disease, stroke, or depression).

\section{Results}

Figure 2 shows the flow diagram of the search of existing burden of disease studies and the main reasons for exclusion. In total, 22 disability weights studies were included. Table 1 presents a detailed overview of the general information, health states that were valued, and methodological design choices of each of the 22 studies. Three studies were global disability weights studies [25-27] and one study included a panel of judges from four countries (United States, South Korea, China, and Taiwan; [28]). All other studies concerned particular countries or regions.

The majority of the 22 disability weights studies developed disability weights for a variety of illnesses. Eight studies concerned disability weights for a specific category (i.e., oral/periodontal diseases [34,36], infectious diseases [29], injuries [20,23,42], urological diseases [38], or stroke [28]. The total number of health states that were valued varied widely from five [28] to 483 [25].

\section{Methodological design choices to render the disability weights \\ Health state description}

Five studies (23\%) used a MAUI model to assess disability weights for health states $[23,34,36,42,44]$. Four of these studies used the EQ-5D model or EQ-6D model (also known as the EQ-5D + model; this model includes an additional cognitive domain) $[23,34,36,42]$. One study developed a new health status classification system, namely the classification and measurement system of functional health (CLAMES), which combines selected attributes of several MAUIs [44]. 


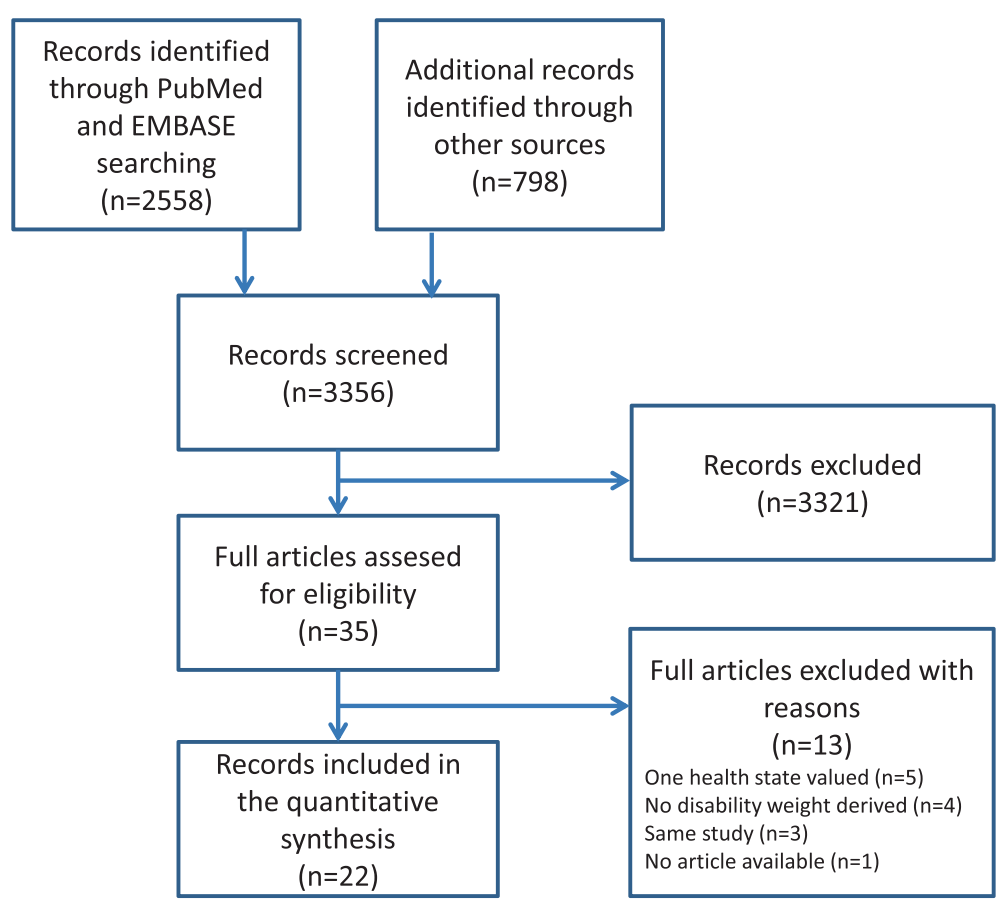

Figure 2 Flow diagram of the search of existing burden of disease studies.

Furthermore, Mathers et al. used a regression model based on the Dutch Disability Weights (DDW) study to derive disability weights for diseases not included in that study and to adjust annualized estimates for duration for acute conditions [31].

Eleven studies (50\%) depicted the health states in a disease-specific way $[19,20,25-27,30,32,33,35,39,43]$. These disease-specific health state descriptions consisted of short descriptions or disability scenarios with illustrations or descriptions that included a disease-specific description of symptoms and generic information. Five studies did not report how the health states were depicted that were valued $[28-30,37,40]$.

\section{Time presentation}

All studies presented the health states as period profiles, apart from three Dutch disability weights studies, which used the annual profile approach $[19,20,39]$. The annual profile disability weights for short-term diseases are much lower compared to period profile disability weights.

\section{Panel composition}

Of the 17 studies that did not use a MAUI, 59\% ( $\mathrm{n}=10)$ asked medical experts or health professionals to value health states $[19,25,28,29,33,35,37,38,40,43]$. Three studies derived preferences from a population panel [20,27,39].
Two studies included two panels: medical experts and people from the population [30,32]. Both studies showed differences between disability weights derived from these two groups. Jelsma et al. report a correlation of 0.32 ( $\mathrm{p}=$ 0.153) between the ranking of health professionals and people from the population. Baltussen et al. showed that medical experts valued five of the nine health states significantly lower compared to people from the population. Üstün et al. derived preferences from health professionals, policymakers, and people with disabilities and their carers [26] and found that the average correlation of rank orders between different informant groups was 0.76 .

The number of judges varied from nine [28] to 30,230 [27].

\section{Valuation method}

Of the non-MAUI studies, nine studies (53\%) derived preferences using a two-step procedure [19,25,29,32,33, $35,37,38,40]$. Firstly, preferences for a small subset of health states were derived using a trade-off method (PTO or TTO). The second step consisted of an interpolation exercise, where the panel of judges was asked to interpolate the remaining health states using the values for the subset. Other studies used only ranking [26,30], pairwise comparison with additional information on population health equivalence [27], or VAS [43] to derive valuations. In three studies, all health states were evaluated with a trade-off method [20,28,39]. Comparison of studies that used more 
Table 1 Included studies: Panel of judges, health state description, and time presentation

\begin{tabular}{|c|c|c|c|c|c|c|c|c|c|c|}
\hline Year & Study & Ref no. & Region & $\begin{array}{l}\text { Multiple or } \\
\text { single cause? }\end{array}$ & $\begin{array}{l}\text { Panel } \\
\text { composition }\end{array}$ & $\mathrm{N}$ panel & $\mathrm{N}$ health states & Health state description & Time presentation & $\begin{array}{l}\text { Valuation methods (\% of total } \\
\text { number of health states valued } \\
\text { by each of the methods) }\end{array}$ \\
\hline 1996 & Murray et al. & {$[25]$} & Global & $M$ & ME & 10 & 483 & DS & PP & $<1 \%$ PTO, 99\% VAS \\
\hline 1997 & Stouthard et al. & [19] & Netherlands & M & ME & 38 & 175 & $D S+E Q-5 D$ & $P P \& A P$ & $10 \%$ PTO, 90\% VAS \\
\hline 1999 & Üstün et al. & [26] & Global & M & HP, PM, PT, PX & 241 & 17 & DS & PP & $100 \%$ ranking \\
\hline 2000 & Havelaar et al. & {$[29]$} & Netherlands & M & ME & 35 & NA & NA & PP & Interpolation \\
\hline 2000 & Jelsma et al. & {$[30]$} & Zimbabwe & M & $\mathrm{PP}, \mathrm{ME}$ & 68 & 22 & NA & PP & VAS (ranking) \\
\hline 2000 & Mathers et al. & [31] & Australia & M & Model & - & Model & MAUI (EQ-6D) + DDW & PP & EQ-6D: Not applicable \\
\hline 2002 & Baltussen et al. & [32] & Burkina Faso & M & $\mathrm{PP}, \mathrm{HP}$ & 56 & 9 & DS (scenarios) & PP & Adapted VAS/interpolation \\
\hline 2003 & Schwarzinger et al. & [33] & Europe & M & ME, NHP & 232 & 15 & $D S+E Q-5 D$ & PP & $100 \%$ VAS, $60 \%$ TTO, 60\% PTO \\
\hline 2004 & Brennan et al. & [34] & Australia & S (oral) & Model & - & 18 & MAUI (EQ-5D) & PP & EQ-6D: Not applicable \\
\hline 2005 & Kruijshaar et al. & [35] & Netherlands & M & ME & 49 & 9 & $D S+E Q-5 D$ & PP & $100 \%$ interpolation \\
\hline 2007 & Brennan et al. & {$[36]$} & Australia & S (oral) & Model & - & 6 & MAUI (EQ-5D) & PP & EQ-6D: not applicable \\
\hline 2007 & Yoon et al. & [37] & Korea & M & ME & 30 & 123 & NA & PP & 13\% PTO, 87\% interpolation \\
\hline 2008 & Basiri et al. & [38] & Iran & S (urologic) & ME & 10 & 76 & NA & PP & $100 \%$ interpolation \\
\hline 2008 & Haagsma et al. & {$[20]$} & Netherlands & S (injury) & PP & 143 & 44 & $D S+E Q-5 D$ & $A P$ & $100 \%$ VAS, $100 \%$ TTO \\
\hline 2008 & Haagsma et al. & [39] & Netherlands & M & PP & 107 & 39 & $D S+E Q-5 D$ & AP & $100 \%$ VAS, $100 \%$ PTO \\
\hline 2009 & Haagsma et al. & [23] & Netherlands & S (injury) & Model & - & 7 & MAUI (EQ-5D) & PP & EQ-5D: not applicable \\
\hline 2009 & Hong et al. & {$[28]$} & US/Southeast Asia & S (stroke) & ME & 9 & 5 & NA & NA & 100\% РTO \\
\hline 2009 & Lai et al. & {$[40]$} & Estonia & M & ME & 25 & 283 & DS & PP & 9\% PTO, 91\% VAS \\
\hline 2010 & Kwong et al. & [41] & Canada & M & Model & - & Model & MAUI (CLAMES) & PP & CLAMES: not applicable \\
\hline 2011 & Lyons et al. & {$[42]$} & UK & S (injury) & Model & - & 13 & MAUI (EQ-5D) & PP & EQ-5D: not applicable \\
\hline 2012 & Salomon et al. & [27] & Global & M & PP & 30230 & 220 & DS (without label) & PP & 100\% Paired comparison \\
\hline 2011 & Van Spijker et al. & [43] & Netherlands & M & ME & 16 & 12 & $D S+E Q-5 D$ & PP & $100 \%$ VAS \\
\hline
\end{tabular}

Multiple or single cause of disease: $M=$ multiple, $S=$ single

Panel: $\mathrm{ME}=$ medical experts, $\mathrm{HP}=$ health professionals, $\mathrm{PM}=$ policymakers, $\mathrm{PT}=$ patients/people with disabilities, $\mathrm{PX}=$ patient proxies, $\mathrm{PP}=$ population.

Health state description: $\mathrm{DS}=$ disease-specific, MAUI = generic multi-attribute utility .

$\mathrm{EQ}-5 \mathrm{D}=$ multi-attribute utility instrument that consists of five attributes (mobility, self-care, usual activities, pain/discomfort. and anxiety/depression).

$\mathrm{EQ}-6 \mathrm{D}=\mathrm{EQ}-5 \mathrm{D}$ appended with a cognitive attribute.

Clames model = Classification and Measurement System of Functional Health; a combination of HUI, SF36, and EQ-5D attributes.

Time presentation: $\mathrm{PP}=$ period profile, $\mathrm{AP}=$ annual profile.

Valuation method: VAS = visual analog scale, TTO = time trade-off, PTO = person trade-off. 
than one valuation technique showed that agreement of rankings with VAS were slightly higher compared to agreement of rankings with TTO/PTO [19,20,33,39].

\section{Experimental design}

Table 2 presents an overview of the experimental design of the 22 studies. Apart from the GBD 2010 disability weights study [27], the disability weights were derived using a written questionnaire. Some studies arranged a panel meeting with group discussion during which preferences were derived, whereas other studies used individual questionnaires. Also, a combination of panel meetings and individual questionnaires were used.

\section{Comparison of disability weights}

Comparisons of disability weights for 15 specific disease and injury groups shows that there is large variation in disease stages that are used in the studies (Table 3). For instance, the number of health states of CVA/stroke ranges from one [40] to five [27,28]. Also, there is large variation between studies in the values of the disability weights for similar health states. For instance, the disability weight for paraplegia ranges from 0.047 (treated paraplegia) and 0.440 (untreated paraplegia) [27] to 0.725 [25], and the disability weight for severe depression ranges from 0.147 [40] to 0.83 [19]. Particularly in the case of mild health states, the disability weight can differ by a factor of two or more. The disability weight for cystitis ranges from 0.01 [19] to 0.023 [41]. For severe gastroenteritis, the disability weights (period profile) range from 0.061 [27] to 0.393 [29].

For four studies, we have tabulated the rankings of 12 diseases and calculated the rank order correlation ( $T$ ) for each of the sets of disability weights. The results shown in Table 4 reveal that there is consistency in the rankings between the GBD 1996, the DDW, and the Estonian disability weights study, with T ranging between 0.426 ( $\mathrm{p}<$ $0.05)$ and $0.626(\mathrm{p}<0.01)$. However, the rank order correlations showed a lack of consistency in the rankings of

Table 2 Experimental design used to render the disability weights

\begin{tabular}{lll}
\hline Experimental design & $\begin{array}{l}\text { Number } \\
\text { of studies }\end{array}$ & References \\
\hline $\begin{array}{l}\text { Panel meeting/focus } \\
\text { group discussion }\end{array}$ & 7 & {$[25,29,30,33,37,40,45]$} \\
Questionnaire & 4 & {$[27,35,38,43]$} \\
Panel meeting + questionnaire & 3 & {$[19,20,39]$} \\
Questionnaire + panel meeting & 1 & {$[32]$} \\
Questionnaire + panel meeting + & 1 & {$[28]$} \\
questionnaire & & \\
Interview & 2 & {$[26,27]$} \\
\hline
\end{tabular}

the GBD 2010 study and the other three disability weights studies included in the comparison.

It seems that studies that used ranking and VAS and studies that provided a short disease-specific health state description resulted in slightly worse disability weights compared to studies that presented generic information on functional health in addition to the disease-specific information (Table 3). However, the actual descriptions of each of the selected conditions were not available. Therefore, it was not possible to perform a detailed analysis to assess whether the differences are related to the presentation of the health state and/or other methodological design choices.

\section{Discussion}

Twenty-two disability weights studies were included in the review. The total number of health states valued in these studies varied from five to more than 400 . The results of this systematic review showed that there is variation in methods used to derive disability weights. However, most studies used a disease-specific description of the health state, a panel that consisted of medical experts, and a nonpreference-based valuation method to assess the values for the majority of the disability weights. Comparisons of disability weights across 15 specific disease and injury groups showed that the subdivision of a disease into separate health states (stages) differed markedly. Additionally, weights for similar health states differed, particularly in the case of mild diseases, for which the disability weight differed by a factor of two or more.

\section{Coverage of diseases and disease staging}

As mentioned above, we found marked differences in coverage of diseases and subdivision of a disease or injury into different health states. The GBD 1996 and the Estonian disability weights sets cover a wider range of conditions than the Dutch disability weights, but are generally less specific in terms of the specific disease stages to which they refer. The set of Dutch disability weights covers a restricted range of conditions compared to the GBD disability weights, but it provides more detailed differentiation between disease stages and severities, thus allowing more detailed disease models in estimating the YLDs than is possible with the GBD or Estonian disability weights [40].

Disability weights studies that focused on a single cause of disease (e.g., periodontal disease, stroke, or depression) also included more detailed disease stages. Often these studies were conducted because the disability weights that are available from the GBD 1996 set are not tailored to the available data on incidence or prevalence. If, for example, the impact of the disease among incident cases is markedly better or worse than that represented by the available "disability weights", data on 
Table 3 Disability weight of eight diseases/injuries

\begin{tabular}{|c|c|c|c|c|c|c|c|c|c|}
\hline & $\begin{array}{l}\text { Author(s) of } \\
\text { the study }\end{array}$ & $\begin{array}{l}\text { Chronic sequelae } \\
\text { of CVA/stroke }\end{array}$ & Paraplegia & Dental caries & $\begin{array}{l}\text { Rheumatoid } \\
\text { arthritis }\end{array}$ & Diabetes & Depression & Gastro-enteritis & $\begin{array}{l}\text { Acute } \\
\text { cystitis }\end{array}$ \\
\hline$[25]$ & $\begin{array}{l}\text { Murray } \\
\text { et al., } 1996\end{array}$ & $\begin{array}{l}\text { Untreated } 0.282 \text { (varies } \\
\text { with age between } 0.262 \text { - } \\
0.301 \text { ); treated } 0.241 \text { (varies } \\
\text { with age between } 0.224-0.258 \text { ) }\end{array}$ & 0.725 & 0.081 & $\begin{array}{l}\text { Untreated } 0.233 \text {, } \\
\text { treated } 0.174\end{array}$ & $\begin{array}{l}\text { Treated } 0.012 ; \\
\text { untreated } 0.033\end{array}$ & $\begin{array}{l}\text { Treated } 0.302 ; \\
\text { Untreated } 0.600\end{array}$ & $\begin{array}{l}0.105 \text { (varies with } \\
\text { age between } \\
0.086-0.119 \text { ) }\end{array}$ & - \\
\hline$[19,46]$ & $\begin{array}{l}\text { Stouthard } \\
\text { et al., } 1997\end{array}$ & $\begin{array}{l}\text { Mild impairments } \\
0.36 \text { (Cl } 0.23-0.49) ; \\
\text { Moderate } \\
\text { impairments } 0.63 \\
\text { (Cl } 0.543-0.718) ; \\
\text { Severe impairments } \\
0.92 \text { (Cl } 0.853-0.994)\end{array}$ & $\begin{array}{l}0.57 \\
\text { (Cl } 0.489-0.651)\end{array}$ & $\begin{array}{l}0.01 \\
(\mathrm{Cl} 0.001-0.009)\end{array}$ & $\begin{array}{l}\text { Mild } 0.21 \\
(\mathrm{Cl} 0.127-0.303) ; \\
\text { moderate } 0.37 \\
(\mathrm{Cl} 0.219-0.515) ; \\
\text { severe } 0.94 \\
(\mathrm{Cl} 0.92-0.961)\end{array}$ & $\begin{array}{l}\text { Uncomplicated } 0.07 \\
\text { (Cl 0.047-0.094; with } \\
\text { neuropathy 0.19 } \\
\text { (Cl 0.126-0.255); with } \\
\text { nephropathy 0.29 } \\
\text { (Cl 0.201-0.38) }\end{array}$ & $\begin{array}{l}\text { Mild 0.14 } \\
\text { (Cl 0.086-0.194); } \\
\text { moderate 0.35 } \\
\text { (Cl 0.272-0.425); } \\
\text { severe 0.76 } \\
\text { (Cl 0.556-0.971); } \\
\text { severe with } \\
\text { psychotic } \\
\text { features } \\
0.83 \text { (Cl } 0.748- \\
0.916)\end{array}$ & $\begin{array}{l}\text { Uncomplicated } \\
\text { course } 0.01 \\
\text { (Cl 0.001-0.009); } \\
\text { complicated } \\
\text { course } 0.03 \\
\text { (Cl 0.018-0.039) }\end{array}$ & $\begin{array}{l}0.01 \\
(\mathrm{Cl} 0-0.039)\end{array}$ \\
\hline [26] & $\begin{array}{l}\text { Üstün } \\
\text { et al., } 1999\end{array}$ & - & $r$ & - & r & & r & - & - \\
\hline [29] & $\begin{array}{l}\text { Havelaar } \\
\text { et al., } 2000\end{array}$ & - & - & - & - & & - & $\begin{array}{l}\text { Severe gastroenteritis } \\
0.393 \text { (Cl } 0.049-0.821)\end{array}$ & \\
\hline [30] & $\begin{array}{l}\text { Jelsma et al., } \\
2000\end{array}$ & - & $r$ & - & $r$ & - & $r$ & - & - \\
\hline$[31,47]$ & $\begin{array}{l}\text { Mathers et al., } \\
2000\end{array}$ & - & - & $\begin{array}{l}\text { Episode resulting } \\
\text { in tooth loss } \\
0.014\end{array}$ & - & - & - & - & - \\
\hline [32] & $\begin{array}{l}\text { Baltussen } \\
\text { et al., } 2002\end{array}$ & - & $\begin{array}{l}\text { PP: } 0.42 ; \\
\text { HP: } 0.55\end{array}$ & - & - & $\begin{array}{l}\text { PP: } 0.49 ; \\
\text { HP: } 0.34\end{array}$ & $\begin{array}{l}\text { PP: } 0.74 ; \\
\text { HP: } 0.66\end{array}$ & - & \\
\hline [33] & $\begin{array}{l}\text { Schwarzinger } \\
\text { et al., } 2003\end{array}$ & $\begin{array}{l}\text { Moderate impairments } \\
0.68\end{array}$ & - & - & - & $\begin{array}{l}\text { Uncomplicated } \\
0.34\end{array}$ & Severe 0.78 & - & \\
\hline [34] & $\begin{array}{l}\text { Brennan } \\
\text { et al., } 2004\end{array}$ & - & - & $\begin{array}{l}0.044 \\
(0.013-0.076)\end{array}$ & - & - & - & - & - \\
\hline [35] & $\begin{array}{l}\text { Kruijshaar } \\
\text { et al., } 2005\end{array}$ & & - & - & - & & $\begin{array}{l}\text { Mild } 0.19 \\
(\mathrm{Cl} 0.16-0.22) ; \\
\text { moderate } 0.51 \\
\text { (Cl } 0.46-0.55) ; \\
\text { severe } 0.84 \\
(0.80-0.88)\end{array}$ & - & \\
\hline [36] & $\begin{array}{l}\text { Brennan } \\
\text { et al., } 2007\end{array}$ & - & - & - & - & - & - & - & - \\
\hline [37] & $\begin{array}{l}\text { Yoon et al., } \\
2007\end{array}$ & NA & NA & NA & NA & NA & NA & NA & NA \\
\hline [38] & $\begin{array}{l}\text { Basiri et al., } \\
2008\end{array}$ & - & - & - & - & - & - & - & $\begin{array}{l}0.018 \\
(-0.047- \\
0.083)\end{array}$ \\
\hline
\end{tabular}


Table 3 Disability weight of eight diseases/injuries (Continued)

\begin{tabular}{|c|c|c|c|c|c|c|c|c|c|}
\hline [20] & $\begin{array}{l}\text { Haagsma } \\
\text { et al., } 2008\end{array}$ & - & $\begin{array}{l}\text { Acute } 0.563(0.495- \\
0.631) \text {, stable } 0.656 \\
(0.525-0.786)\end{array}$ & - & - & - & - & - & - \\
\hline [39] & $\begin{array}{l}\text { Haagsma } \\
\text { et al., } 2008\end{array}$ & - & $\begin{array}{l}0.551 \\
(0.36-0.74)\end{array}$ & - & - & - & - & - & - \\
\hline [23] & $\begin{array}{l}\text { Haagsma } \\
\text { et al., } 2009\end{array}$ & - & - & - & - & - & - & $\begin{array}{l}\text { Mild } 0.010(-0.005-0.025) \text {, } \\
\text { moderate } 0.015(0.005-0.025) \text {, } \\
\text { severe } 0.041(0.014-0.067)\end{array}$ & - \\
\hline$[28]$ & $\begin{array}{l}\text { Hong et al., } \\
2010\end{array}$ & $\begin{array}{l}\text { mRS1 } 0.046 \text { (Cl 0.004-0.088); } \\
\text { mRS2 } 0.212(0.175-0.250) ; \\
\text { mRS3 } 0.331(0.292-0.371) ; \\
\text { mRS4 } 0.652(0.625-0.678) ; \\
\text { mRS5 } 0.944(0.873-1.015)\end{array}$ & - & - & - & - & - & - & - \\
\hline$[40]$ & $\begin{array}{l}\text { Lai et al., } \\
2009\end{array}$ & 0.547 & 0.669 & 0.078 & 0.203 & $\begin{array}{l}\text { Insulin dependent } \\
0.264 \text {, insulin non- } \\
\text { dependent } 0.029\end{array}$ & 0.147 & 0.011 & \\
\hline$[41,44]$ & $\begin{array}{l}\text { Kwong et al., } \\
2010\end{array}$ & - & - & - & $\begin{array}{l}\text { Active episode } 0.262 ; \\
\text { chronic active } 0.058 ; \\
\text { advanced damage } 0.465\end{array}$ & - & $\begin{array}{l}\text { Mild } 0.122 ; \\
\text { moderate } 0.440 \\
\text { severe } 0.558\end{array}$ & $\begin{array}{l}\text { Mild } 0.023 \text {; moderate } 0.041 \text {; } \\
\text { severe } 0.086\end{array}$ & 0.023 \\
\hline$[42]$ & $\begin{array}{l}\text { Lyons et al., } \\
2011\end{array}$ & - & - & - & - & - & - & - & - \\
\hline \multirow[t]{9}{*}{ [27] } & \multirow[t]{9}{*}{$\begin{array}{l}\text { Salomon } \\
\text { et al., } 2012\end{array}$} & $\begin{array}{l}\text { mild: } 0.021 \\
(0.011-0.037)\end{array}$ & $\begin{array}{l}\text { untreated } 0.440 \\
(\mathrm{Cl} 0.290-0.588) \text {, } \\
\text { treated }\end{array}$ & $\begin{array}{l}\text { Symptomatic: } \\
0.012(0.005- \\
0.023)\end{array}$ & $\begin{array}{l}\text { Legs, mild: } 0.023 \\
(0.013-0.039)\end{array}$ & - & $\begin{array}{l}\text { Mild: } 0.159 \\
\text { (UI 0.107-0.223) }\end{array}$ & Mild: $0.061(0.036-0.093)$ & - \\
\hline & & $(0.050-0.110)$ & \multirow{7}{*}{$\begin{array}{l}0.047 \\
(\mathrm{Cl} 0.029-0.072)\end{array}$} & & \multirow{2}{*}{$\begin{array}{l}\text { Legs, moderate: } 0.079 \\
(0.053-0.115)\end{array}$} & & \multirow{2}{*}{$\begin{array}{l}\text { Moderate: } 0.406 \\
\text { (UI 0.276-0.551) }\end{array}$} & \multirow[t]{2}{*}{ Moderate: $0.202(0.133-0.299)$} & \\
\hline & & moderate plus & & & & & & & \\
\hline & & $\begin{array}{l}\text { cognition problems: } \\
0.312(0.211-0.433)\end{array}$ & & & $\begin{array}{l}\text { Legs, severe: } 0.171 \\
(0.117-0.240)\end{array}$ & & \multirow[t]{6}{*}{$\begin{array}{l}\text { Severe: } 0.655 \\
\text { (UI 0.469-0.816) }\end{array}$} & \multirow[t]{6}{*}{ Severe: 0.281 (0.184-0.399) } & \\
\hline & & $\begin{array}{l}\text { severe: } 0.539 \\
(0.363-0.705)\end{array}$ & & & $\begin{array}{l}\text { Arms, mild: } 0.024 \\
(0.014-0.041)\end{array}$ & & & & \\
\hline & & & & & $\begin{array}{l}\text { Arms, moderate: } \\
0.114(0.077-0.159)\end{array}$ & & & & \\
\hline & & & & & $\begin{array}{l}\text { Arms, severe: } 0.292 \\
(0.077-0.159)\end{array}$ & & & & \\
\hline & & & & & $\begin{array}{l}\text { Generalised, moderate: } \\
0.292(0.197-0.410)\end{array}$ & & & & \\
\hline & & $\begin{array}{l}\text { severe plus cognitive } \\
\text { problems: } 0.567(0.394-0.738)\end{array}$ & & & $\begin{array}{l}\text { Generalised severe: } \\
0.606(0.42-0.77)\end{array}$ & & & & \\
\hline [43] & $\begin{array}{l}\text { Van Spijker } \\
\text { et al., } 2011\end{array}$ & - & - & - & $0.33(\mathrm{Cl} 0.05-0.61)$ & - & $\begin{array}{l}\text { Severe with } \\
\text { psychotic } \\
\text { features } 0.74 \\
\text { (Cl 0.40-1.08) }\end{array}$ & - & - \\
\hline
\end{tabular}


Table 3 Disability weight of eight diseases/injuries (Continued)

\begin{tabular}{|c|c|c|c|c|c|c|c|c|}
\hline $\begin{array}{l}\text { Ref } \\
\text { nr. }\end{array}$ & $\begin{array}{l}\text { Author(s) of } \\
\text { the study }\end{array}$ & Severe anemia & Infertility & $\begin{array}{l}\text { Below the knee } \\
\text { amputation }\end{array}$ & Deafness & $\begin{array}{l}\text { Mild mental } \\
\text { retardation }\end{array}$ & Dementia & Blindness \\
\hline [25] & $\begin{array}{l}\text { Murray et al., } \\
1996\end{array}$ & $\begin{array}{l}0.087-0.093 \text { (varies } \\
\text { with age) }\end{array}$ & 0.180 & 0.3 & $\begin{array}{l}\text { Untreated } 0.213-0.233 ; \\
\text { treated } 0.168-0.175\end{array}$ & $\begin{array}{l}\text { Untreated 0.469-0.485; } \\
\text { treated 0.394-0.468 }\end{array}$ & $\begin{array}{l}\text { Untreated } 0.600 ; \\
\text { treated } 0.302\end{array}$ & $\begin{array}{l}\text { Untreated 0.600; treated } \\
0.488-0.493\end{array}$ \\
\hline$[19,46]$ & $\begin{array}{l}\text { Stouthard } \\
\text { et al.,1997 }\end{array}$ & & $\begin{array}{l}0.11 \\
(\mathrm{Cl} 0.03-0.20)\end{array}$ & & $\begin{array}{l}\text { Childhood } 0.23(0.12-0.33) \text {; } \\
\text { elderly } 0.37(0.34-0.41)\end{array}$ & 0.29 (Cl 0.09-0.50) & $\begin{array}{l}\text { Mild } 0.27(\mathrm{Cl} \\
0.13-0.42) ; \\
\text { moderate } 0.63 \\
(\mathrm{Cl} 0.41-0.86) ; \\
\text { severe } 0.94 \\
(\mathrm{Cl} 0.93-0.95)\end{array}$ & 0.43 (Cl 0.34-0.52) \\
\hline [26] & $\begin{array}{l}\text { Üstün et al., } \\
1999\end{array}$ & r & r & r & r & $r$ & r & $r$ \\
\hline [29] & $\begin{array}{l}\text { Havelaar } \\
\text { et al., } 2000\end{array}$ & - & - & - & - & - & - & - \\
\hline [30] & $\begin{array}{l}\text { Jelsma et al., } \\
2000\end{array}$ & r & r & r & r & r & r & $r$ \\
\hline$[31,47]$ & $\begin{array}{l}\text { Mathers et al., } \\
2000\end{array}$ & & - & - & - & - & - & - \\
\hline [32] & $\begin{array}{l}\text { Baltussen } \\
\text { et al., } 2002\end{array}$ & - & - & - & PP: 0.16; HP: 0.11 & - & - & PP 0.35; HP 0.36 \\
\hline [33] & $\begin{array}{l}\text { Schwarzinger } \\
\text { et al., } 2003\end{array}$ & - & - & - & - & - & $\begin{array}{l}\text { Mild dementia } \\
0.46\end{array}$ & - \\
\hline [34] & $\begin{array}{l}\text { Brennan } \\
\text { et al., } 2004\end{array}$ & - & - & - & - & - & - & - \\
\hline [35] & $\begin{array}{l}\text { Kruijshaar } \\
\text { et al., } 2005\end{array}$ & - & - & - & - & - & - & - \\
\hline [36] & $\begin{array}{l}\text { Brennan } \\
\text { et al., } 2007\end{array}$ & - & - & - & - & - & - & - \\
\hline [37] & $\begin{array}{l}\text { Yoon et al., } \\
2007\end{array}$ & NA & NA & NA & NA & NA & NA & NA \\
\hline [38] & $\begin{array}{l}\text { Basiri et al., } \\
2008\end{array}$ & - & - & - & - & - & - & - \\
\hline [20] & $\begin{array}{l}\text { Haagsma } \\
\text { et al., } 2008\end{array}$ & - & - & - & - & - & - & - \\
\hline [39] & $\begin{array}{l}\text { Haagsma } \\
\text { et al., } 2008\end{array}$ & - & - & - & - & - & - & - \\
\hline [23] & $\begin{array}{l}\text { Haagsma } \\
\text { et al., } 2009\end{array}$ & - & - & - & - & - & - & - \\
\hline [28] & $\begin{array}{l}\text { Hong et al., } \\
2010\end{array}$ & - & - & - & - & - & - & - \\
\hline [40] & $\begin{array}{l}\text { Lai et al., } \\
2009\end{array}$ & 0.168 & 0.547 & 0.747 & 0.254 & 0.242 & 0.261 & 0.478 \\
\hline$[41,44]$ & $\begin{array}{l}\text { Kwong et al., } \\
2010\end{array}$ & & - & & & 0.122 & & Diabetic retinopathy 0.248 \\
\hline
\end{tabular}


Table 3 Disability weight of eight diseases/injuries (Continued)

[42] Lyons et al.,

2011

[27] Salon

Primary 0.011

(UI 0.005-0.021);

secondary 0.006

Untreated 0.164 Complete 0.033

(Ul 0.111-0.229); (UI 0.020-0.052);

et al., 2012

(UI 0.112-0.228)

$0.002-0.013$

(UI 0.011-0.035)

complete with

0.031

(Ul 0.018-0.049)

Mild 0.082

0.195

moderate 0.346

(Cl 0.233-0.475)

$\begin{array}{ll}\text { (UI 0.061-0.134) } & \text { severe } 0.438 \\ \text { (CI 0.299-0.584) }\end{array}$

[43] Van Spijker
et al, 2011

$\mathrm{NA}=$ not available, $\mathrm{r}=$ ranking, no actual value was established, $\mathrm{Cl}=95 \%$ confidence interval if reported, $\mathrm{Ul}=$ Uncertainty interval if reported. 
Table 4 Rank order correlations between four disability weights studies

\begin{tabular}{lllll}
\hline & $\begin{array}{l}\text { Murray } \\
\text { et al., 1996 }\end{array}$ & $\begin{array}{l}\text { Stouthard } \\
\text { et al., 1997 }\end{array}$ & $\begin{array}{l}\text { Lai et al., } \\
\text { 2009 }\end{array}$ & $\begin{array}{l}\text { Salomon } \\
\text { et al., 2013 }\end{array}$ \\
\hline Murray et al., 1996 & $\mathrm{X}$ & $0.462^{*}$ & $0.626^{* *}$ & 0.351 \\
Stouthard et al., 1997 & & $X$ & $0.534^{*}$ & 0.107 \\
Lai et al., 2009 & & & $X$ & $0.515^{*}$ \\
Salomon et al., 2013 & & & & $X$ \\
\hline
\end{tabular}

${ }^{* *} p<0.01 ;{ }^{*} p<0.05$

the incidence of a disease cannot be accurately linked to the functional outcomes of that disease. In addition, disability weights for certain health outcomes may not be available or appropriate, e.g., for infectious diseases (Guillain-Barré syndrome, irritable bowel syndrome, reactive arthritis) [39], injuries (concussion) [20], or periodontal disease $[34,36]$.

\section{Panel composition and contextual differences}

Using disability weights based on societal preferences has been recommended, because burden of disease studies are primarily used as a tool for guiding decisionmaking on resource allocation at the population level [3]. Nonetheless, the majority of studies asked medical experts or health professionals to value health states. Three studies asked both medical experts and members of the general public $[26,30,32]$. The results of two of these studies showed significant differences between disability weights derived from these two groups. Also, it should be noted that diseases and injuries rated as less severe by experts in a high-income country might be rated as more burdensome by people in health care in low-income settings. Two studies compared health state valuations among residents of several countries. A study among European countries showed that ranking of health states is similar across countries [33]. However, Üstün et al. found that for the majority of health conditions there were significant differences in ranking between 14 countries. Salomon et al., on the other hand, reported a high degree of consistency between sites, with the exception of one site [27]. Previous studies have shown that there are clear contextual differences in the ways people perceive health problems and how such problems affect their lives [48-52]. The findings from Jelsma et al. suggest that contextual differences may be stronger among lay people compared to health professionals [30]. Further research is needed to gain greater insight into the effect of contextual differences on disability weights.

\section{Health state description}

Five studies used a MAUI model (e.g., EQ-5D or CLAMES) to assess disability weights. A MAUI model describes the health state with generic attributes only, whereas diseasespecific health state descriptions may include disability scenarios with illustrations, a specific description of the symptoms, and/or information on treatment. Diseasespecific health state descriptions have been shown to be more sensitive for the detection and quantification of small changes [53], see e.g. Stouthard et al. [46] who combined disease-specific information with EQ-5D data [46]. They found that low back pain and prostate cancer, health states with a similar EQ-5D profile but a different disease label, yielded different values. This indicates that diseasespecific health state descriptions provide information that is not reflected in the generic health states but which matters for health state valuation. Which information is reflected in the generic health state, however, depends on the MAUI that is used, as they differ in the number and type of health domains that are included, the total number of possible health states, and the health state valuation techniques that are used to assess the weights that are assigned to the health domains. When an extensive disease-specific description of a health state is used, it is important to realize that the description may produce information bias because of message-framing effects [54]. Empirical studies have shown that the manner of depicting the health state affects preferences for these health states [55]. Secondly, including information on the symptoms of the disease, the impact on daily functioning, and duration in the description of the health state may result in cognitive overload of the panel of judges, especially if the panel of judges consists of members of the general public.

We recommend using a combination of a generic and disease-specific health state, because it has been shown that even for expert panels, adding a generic description of functional health status to the diagnostic disease label is necessary to standardize the stimulus $[33,46,56]$. Furthermore, utilizing an unadjusted MAUI model, such as the EQ-5D, to assess disability weights may be inconsistent with the objective of DALYs, because disability weights in GBD and other population-based burden of disease studies are adjusted to ascertain that the burden of disease from all causes adds up to the total burden of disease in the population. The unadjusted MAUI-based disability weights do not have such a restriction.

\section{Time presentation: period versus annual profiles}

Disability weights can be subdivided into period profile and annual profile disability weights. Period profile disability weights assume independence between duration and disability and they require that the health state remains constant over time. This assumption is untenable for disorders that are characterized by a complex timeseverity course [57], because it is impossible to disaggregate complex time patterns into a limited number of homogeneous stages. A solution proposed to overcome 
this problem was the annual profile approach, which describes the health profile over a period of one year [4]. The results of this systematic review showed that the annual profile approach has not been adopted internationally. This may be due to several reasons. Firstly, it has been argued that the annual profile approach may overvalue diseases with a mild and rapid course [58], though this may be corrected by using a relevance criterion for the inclusion of incident or prevalent cases [39]. A second, more practical, reason may be that the annual profile disability weights are rather inflexible with regard to time. If health states with different durations than the duration included in the annual profile are needed, they cannot be derived by back-calculation. Thus, the initial disability weights have to be applied, even though the duration does not match, or a new annual profile disability weight has to be derived with a new panel study.

\section{Valuation methods}

A majority of disability weight studies used ranking, interpolation, paired comparison, or the VAS to assess the values for disability weights. These valuation methods lack the trade-off feature; they do not ask to sacrifice something valuable in order to assess the undesirability of the health state. Therefore, in a technical sense, these studies do not assess preferences but values [14]. The values elicited with VAS, and to a lesser degree with paired comparison, ranking, and interpolation, give information about the relative desirability of a health state compared to other health states (A is valued higher than B in a VAS, therefore A is preferred to $B$ ), but it is impossible to reasonably infer the trade-offs that people are willing to make [6]. Regarding the actual values of the disability weights, many studies have found that health state valuations with the VAS tend to be higher compared to equivalent valuations with choice-based valuation methods $[20,59,60]$. The results from this study appear to support those findings.

\section{Validity}

In the absence of a gold standard for the disability component it is difficult to evaluate the validity of disability weights. One way to study the validity of disability weights is by tabulating and comparing the rankings of matching diseases and injuries of several studies. These comparisons showed a high degree of consistency in ranking between the GBD 1996 study, DDW, the Estonian disability weights study, and the GBD 2010 study. However, it should be noted that to calculate a disability weight for the 12 matching diseases and injuries we needed to aggregate disability weights for different disease stages of several studies very crudely. A second approach to assess validity is to compare the disability weights of disease stages within a certain disease or injury. Many studies subdivided a disease or injury into disease stages and comparison of the disability weights of these disease stages showed that the more severe health states have a higher disability weight compared to less severe health states, indicating high face validity.

\section{Comparison of disability weights}

A major finding of this study is the fact that the values of the disability weights across studies differ markedly. As a result, disability weights from studies with different designs cannot be used interchangeably. This raises the question of whether DALY estimates from studies using different sets of disability weights can be compared to each other, since a disability weight that is twice as high might result in a YLD that is twice as high if the same duration and incidence or prevalence numbers are applied. The GBD 2010 study showed major shifts in rankings of causes of burden of disease, and these differences can, to some extent, be traced back to marked differences in disability weights (e.g., back pain and sensory disability) [61]. Hence, to meet the purpose of the DALY, namely to assess the burden of disease and injury at the population level for comparability of impacts of different diseases and risk factors over time and between regions, it is important to use the same set of universal disability weights.

\section{Conclusions}

Methodological constraints, contextual differences, and practical limitations have urged burden of disease researchers to derive alternative sets of disability weights, each using a different approach with regard to the panel, health state description, and valuation methods, resulting in widely varying values for similar health states. However, in terms of comparability of the resulting YLDs, the global use of the same set of disability weights is preferable.

\section{Competing interest}

$J \mathrm{H}, \mathrm{SP}$, and $\mathrm{AH}$ : No competing interests.

$A C$ and EC work for the European Centre for Infectious Disease Prevention and Control (ECDC) that funded this study.

\section{Authors' contributions}

$\mathrm{JH}, \mathrm{SP}, \mathrm{AC}, \mathrm{EC}$, and $\mathrm{AH}$ developed the study concept and design. JH and SP performed the literature search and data extractions. $\mathrm{JH}, \mathrm{SP}$, and $\mathrm{AH}$ analyzed and interpreted the data. $\mathrm{JH}$ and SP drafted the manuscript. JH, SP, AC, EC, and $\mathrm{AH}$ critically revised the manuscript for important intellectual content. All authors read and approved the final manuscript.

\section{Author details}

${ }^{1}$ Department of Public Health, Erasmus Medical Center, PO Box 2040, 3000 CA Rotterdam, The Netherlands. '2Office of the Chief Scientist, European Centre for Disease Prevention and Control, SE-171 83 Stockholm, Sweden. ${ }^{3}$ National Institute for Public Health and the Environment, Laboratory for Zoonoses and Environmental Microbiology, PO Box 1, 3720 BA Bilthoven, The Netherlands. ${ }^{4}$ Utrecht University, Institute for Risk Assessment Sciences, P.O. Box 80.178, 3508 TD Utrecht, the Netherlands. 


\section{References}

1. Murray CJ: Quantifying the burden of disease: the technical basis for disability-adjusted life years. Bull World Health Organ 1994, 72:429-445.

2. Murray CJL, Lopez AD, Mathers CD: Summary Measures of Population Health: Concepts, Ethics, Measurement and Applications. Geneva: World Health Organization; 2002

3. Field MJ, Gold MR: Summarising Population Health: Directions for the Development and Application of Population Health Metrics. Washington D.C: Institute of Medicine: National Academy Press; 1998.

4. Essink-Bot ML, Bonsel GJ: How to derive disability weights? In Summary Measures of Population Health: Concepts, Ethics, Measurement and Applications. Edited by Murray CJL, Lopez AD, Salomon JA. Geneva: World Health Organization; 2002.

5. Drummond M, O'Brien B, Stoddart GL, Torrance GW: Methods for the Economic Evaluation of Health Care Programmes. Oxford, U.K.: Oxford Medical Publications; 1997.

6. Froberg DG, Kane RL: Methodology for measuring health-state preferences-I: Measurement strategies. J Clin Epidemiol 1989, 42:345-354

7. McNamee $P$, Seymour J: Comparing generic preference-based healthrelated quality-of-life measures: advancing the research agenda. Expert Rev Pharmacoecon Outcomes Res 2005, 5:567-581.

8. Boyd NF, Sutherland HJ, Heasman KZ, Tritchler DL, Cummings BJ: Whose utilities for decision analysis? Med Decis Making 1990, 10:58-67.

9. Sackett $\mathrm{DL}$, Torrance GW: The utility of different health states as perceived by the general public. J Chronic Dis 1978, 31:697-704.

10. Balaban DJ, Sagi PC, Goldfarb NI, Nettler S: Weights for scoring the quality of well-being instrument among rheumatoid arthritis. A comparison to general population weights. Med Care 1986, 24:973-980.

11. Dolders MG, Zeegers MP, Groot W, Ament A: A meta-analysis demonstrates no significant differences between patient and population preferences. J Clin Epidemiol 2006, 59:653-664

12. Haagsma JA: Disability Adjusted Life Years and Acute Onset Disorders: Improving Estimates of the non-Fatal Burden of Injuries and Infectious Intestinal Disease. Rotterdam: Erasmus University Rotterdam; 2010.

13. Murray CJ, Acharya AK: Understanding DALYs (disability-adjusted life years). J Health Econ 1997, 16:703-730.

14. Brazier J, Deverill M, Green C: A review of the use of health status measures in economic evaluation. J Health Serv Res Policy 1999 4:174-184.

15. Hawthorne $\mathrm{G}$, Richardson J: Measuring the value of program outcomes: a review of multiattribute utility measures. Expert Rev Pharmacoecon Outcomes Res 2001, 1:215-228.

16. Essink-Bot ML, Krabbe PF, Bonsel GJ, Aaronson NK: An empirical comparison of four generic health status measures. The Nottingham Health Profile, the Medical Outcomes Study 36-item Short-Form Health Survey, the COOP/WONCA charts, and the EuroQol instrument. Med Care 1997, 35:522-537.

17. Feeny $D$, Furlong $W$, Boyle $M$, Torrance GW: Multi-attribute health status classification systems. Health Utilities Index. Pharmacoeconomics 1995, 7:490-502.

18. Rabin R, de Charro F: EQ-5D: a measure of health status from the EuroQol Group. Ann Med 2001, 33:337-343.

19. Stouthard MEA, Essink-Bot ML, Bonsel GJ, Barendregt JJ, Kramers PGN, Van de Water HPA, Gunning-Schepers LJ, Van der Maas PJ: Disability Weights for Diseases in the Netherlands. Rotterdam: Department of Public Health, Erasmus University Rotterdam; 1997.

20. Haagsma JA, van Beeck EF, Polinder S, Hoeymans N, Mulder S, Bonsel GJ: Novel empirical disability weights to assess the burden of non-fatal injury. Inj Prev 2008, 14:5-10.

21. Johannesson M, Jonsson B, Karlsson G: Outcome measurement in economic evaluation. Health Econ 1996, 5:279-296.

22. Tsuchiya A, Dolan P: The QALY model and individual preferences for health states and health profiles over time: a systematic review of the literature. Med Decis Making 2005, 25:460-467.

23. Haagsma JA, Polinder S, van Beeck EF, Mulder S, Bonsel GJ: Alternative approaches to derive disability weights in injuries: do they make a difference? Qual Life Res 2009, 18:657-665.

24. Brazier J, Ratcliffe J, Salomon JA, Tsuchiya A: Measuring and Valuing Health Benefits for Economic Evaluation. Oxford: Oxford University Press; 2007.

25. Murray CJL, Lopez AD: The global burden of disease: A comprehensive assessment of mortality and disability from diseases, injuries and risk factors in 1990 and projected to 2020. Cambridge: Harvard University Press; 1996.
26. Ustun TB, Rehm J, Chatterji S, Saxena S, Trotter R, Room R, Bickenbach J: Multiple-informant ranking of the disabling effects of different health conditions in 14 countries. WHO/NIH Joint Project CAR Study Group. Lancet 1999, 354:111-115.

27. Salomon JA, Vos T, Hogan DR, Gagnon M, Naghavi M, Mokdad A, Begum N, Shah R, Karyana M, Kosen S, Farje MR, Moncada G, Dutta A, Sazawal S, Dyer A, Seiler J, Aboyans V, Baker L, Baxter A, Benjamin EJ, Bhalla K, Bin Abdulhak A, Blyth F, Bourne R, Braithwaite T, Brooks P, Brugha TS, Bryan-Hancock C, Buchbinder R, Burney $P$, et al: Common values in assessing health outcomes from disease and injury: disability weights measurement study for the Global Burden of Disease Study 2010. Lancet 2012, 380:2129-2143.

28. Hong KS, Saver JL: Quantifying the value of stroke disability outcomes: WHO global burden of disease project disability weights for each level of the modified Rankin Scale. Stroke 2009, 40:3828-3833.

29. Havelaar AH, de Wit MA, van Koningsveld R, van Kempen E: Health burden in the Netherlands due to infection with thermophilic Campylobacter spp. Epidemiol Infect 2000, 125:505-522.

30. Jelsma J, Chivaura VG, Mhundwa K, De Weerdt W, de Cock P: The global burden of disease disability weights. Lancet 2000, 355:2079-2080.

31. Mathers CD, Vos ET, Stevenson CE, Begg SJ: The Australian Burden of Disease Study: measuring the loss of health from diseases, injuries and risk factors. Med J Aust 2000, 172:592-596.

32. Baltussen RM, Sanon M, Sommerfeld J, Wurthwein R: Obtaining disability weights in rural Burkina Faso using a culturally adapted visual analogue scale. Health Econ 2002, 11:155-163.

33. Schwarzinger M, Stouthard ME, Burstrom K, Nord E: Cross-national agreement on disability weights: the European Disability Weights Project. Popul Health Metr 2003, 1:9

34. Brennan DS, Spencer AJ: Disability weights for the burden of oral disease in South Australia. Popul Health Metr 2004, 2:7.

35. Kruijshaar ME, Hoeymans N, Spijker J, Stouthard ME, Essink-Bot ML: Has the burden of depression been overestimated? Bull World Health Organ 2005, 83:443-448

36. Brennan DS, Spencer AJ, Roberts-Thomson KF: Quality of life and disability weights associated with periodontal disease. J Dent Res 2007, 86:713-717.

37. Yoon SJ, Bae SC, Lee SI, Chang H, Jo HS, Sung JH, Park JH, Lee JY, Shin Y: Measuring the burden of disease in Korea. J Korean Med Sci 2007, 22:518-523.

38. Basiri A, Mousavi SM, Naghavi M, Araghi IA, Namini SA: Urologic diseases in the Islamic Republic of Iran: what are the public health priorities? East Mediterr Health J 2008, 14:1338-1348.

39. Haagsma JA, Havelaar AH, Janssen BM, Bonsel GJ: Disability Adjusted Life Years and minimal disease: application of a preference-based relevance criterion to rank enteric pathogens. Popul Health Metr 2008, 6:7.

40. Lai T, Habicht J, Kiivet RA: Measuring burden of disease in Estonia to support public health policy. Eur J Public Health 2009, 19:541-547.

41. Kwong JC, Crowcroft NS, Campitelli MA, Ratnasingham S, Daneman N, Deeks SL, Manuel DG: Ontario Burden of Infectious Disease Study. Toronto: Ontario Agency for Health Protection and Promotion and the Institute for Clinical Evaluative Sciences; 2010.

42. Lyons RA, Kendrick D, Towner EM, Christie N, Macey S, Coupland C, Gabbe $\mathrm{BJ}$ : Measuring the population burden of injuries-implications for global and national estimates: a multi-centre prospective UK longitudinal study. PLoS Med 2011, 8:e1001140.

43. van Spijker BA, van Straten A, Kerkhof AJ, Hoeymans N, Smit F: Disability weights for suicidal thoughts and non-fatal suicide attempts. J Affect Disord 2011, 134:341-347.

44. Kwong JC, Ratnasingham S, Campitelli MA, Daneman N, Deeks SL, Manuel DG, Allen VG, Bayoumi AM, Fazil A, Fisman DN, Gershon AS, Gournis E, Heathcote EJ, Jamieson FB, Jha P, Khan KM, Majowicz SE, Mazzulli T, McGeer AJ, Muller MP, Raut A, Rea E, Remis RS, Shahin R, Wright AJ, Zagorski B, Crowcroft NS: The impact of infection on population health: results of the Ontario burden of infectious diseases study. PLOS One 2012, 7:e44103.

45. Yoon SJ, Kwon YD, Kim BY: Estimating the disability weight of major cancers in Korea using Delphi method. Korean J Prev Med 2000, 33:409-414.

46. Stouthard ME, Essink-Bot ML, Bonsel GJ: Disability weights for diseases. A modified protocol and results for a Western European region. Eur J Public Health 2000, 10:24-30

47. Mathers CD, Vos C, Stevenson C: The Burden of Disease and Injury in Australia. Canberra: AlHW; 1999. 
48. Diener E, Diener M: Cross-cultural correlates of life satisfaction and self-esteem. J Pers Soc Psychol 1995, 68:653-663.

49. Hampton NZ, Marshall A: Culture, gender, self-efficacy and life satisfaction: a comparison between American and Chinese people with spinal cord injuries. J Rehabil 2000, 66:21-28.

50. Yiu EM, Ho EM, Ma EP, Verdolini Abbott K, Branski R, Richardson K, Li NY. Possible cross-cultural differences in the perception of impact of voice disorders. J Voice 2010, 25:348-353.

51. Badia X, Roset M, Herdman M, Kind P: A comparison of United Kingdom and Spanish general population time trade-off values for EQ-5D health states. Med Decis Making 2001, 21:7-16.

52. Tsuchiya A, Ikeda S, Ikegami N, Nishimura S, Sakai I, Fukuda T, Hamashima C, Hisashige A, Tamura M: Estimating an EQ-5D population value set: the case of Japan. Health Econ 2002, 11:341-353.

53. Patrick DL, Deyo RA: Generic and disease-specific measures in assessing health status and quality of life. Med Care 1989, 27:S217-S232.

54. Tversky A, Kahneman D: The framing of decisions and the psychology of choice. Science 1981, 211:453-458.

55. Kuehberger A: The influence of framing on risky decisions: A meta-analysis. Organ Behav Hum Decis Process 1998, 75:23-55.

56. Anand S, Hanson K: Disability-adjusted life years: a critical review. J Health Econ 1997, 16:685-702.

57. Janssen MF, Birnie E, Bonsel G: Feasibility and reliability of the annual profile method for deriving QALYs for short-term health conditions. Med Decis Making 2008, 28:500-510

58. Vos T: The case against annual profiles for the valuation of disability weights. In Summary Measures of Population Health: Concepts, Ethics, Measurement and Application. Edited by Murray CJL, Salomon JA, Mathers CD, Lopez AD. Geneva: World Health Organization; 2002.

59. Read JL, Quinn RJ, Berwick DM, Fineberg HV, Weinstein MC: Preferences for health outcomes. Comparison of assessment methods. Med Decis Making 1984, 4:315-329.

60. Nord E: The validity of a visual analogue scale in determining social utility weights for health states. Int J Health Plann Manage 1991, 6:234-242.

61. Murray CJ, Vos T, Lozano R, Naghavi M, Flaxman AD, Michaud C, Ezzati M, Shibuya K, Salomon JA, Abdalla S, Aboyans V, Abraham J, Ackerman I, Aggarwal R, Ahn SY, Ali MK, Alvarado M, Anderson HR, Anderson LM, Andrews KG, Atkinson C, Baddour LM, Bahalim AN, Barker-Collo S, Barrero LH, Bartels DH, Basáñez MG, Baxter A, Bell ML, Benjamin EJ, et al: Disability-adjusted life years (DALYs) for 291 diseases and injuries in 21 regions, 1990-2010: a systematic analysis for the Global Burden of Disease Study 2010. Lancet 2013, 380:2197-2223.

doi:10.1186/s12963-014-0020-2

Cite this article as: Haagsma et al:: Review of disability weight studies: comparison of methodological choices and values. Population Health Metrics 2014 12:20

\section{Submit your next manuscript to BioMed Central and take full advantage of:}

- Convenient online submission

- Thorough peer review

- No space constraints or color figure charges

- Immediate publication on acceptance

- Inclusion in PubMed, CAS, Scopus and Google Scholar

- Research which is freely available for redistribution 